\section{Commercial Solvents Award in Antibiotics}

Drs. Ibert C. Wells (Syracuse, N.Y.), Edwin E. Hays (Chicago, Ill.), E. A. Doisy (St. Louis, Mo.), and William L. Gaby (Philadelphia, Pa.) have been awarded the 1952 Commercial Solvents Award in Antibiotics for work on antibiotics from Pseudomonas aeruginosa. These workers have demonstrated that, in addition to pyocyanine, Pseudomonas aeruginosa produces several other antibacterial agents; they have worked out methods of isolation, separation and purification of these agents, defined their physical and chemical properties, proposed structural formulæ for them and, by degradation and synthesis, proved the acceptability of the proposed formulæ. The Commercial Solvents Antibiotics Award was established in 1950 and is administered by the Society of American Bacteriologists. It consists of a gold medal and 1,000 dollars, and is awarded to any person or group of persons working in the western hemisphere who have made an outstanding contribution in the field of antibiotics during the past year.

\section{Links between School and University}

BeLIEving that the latter years of a pupil's time at school and the years at a university should be as closely integrated as possible, the Council and Senate of the University of Leeds are building up the closest possible links with schools. Last year, for example, two booklets were prepared describing the courses available in science and technology. These booklets are intended to help careers masters and others to advise school boys and girls in their latter years about university courses that will best qualify them for the careers of their choice. The University has also become aware that it must devote close attention each year to the selection of new students of the right academic standards to keep the size of the University about constant. In the annual report for 1951-52, the vice-chancellor, Sir Charles Morris, suggests that this is most likely to be achieved by making a selection from among the applicants as early as possible. The fact that most candidates still apply to several universities and university colleges is the cause of much wasted effort and of much disappointment; it would appear that joint action by universities and university colleges in this matter is both desirable and necessary. To some extent the problem of selection has been made more difficult by the change from School Certificate and Higher School Certificate examinations to the General Certificate of Education examinations. On the other hand, headmasters and headmistresses are giving most helpful confidential reports, and heads of university departments have been able, to a much larger extent than hitherto, to interview applicants for admission and make a personal assessment of promise and suitability.

\section{Use of Antibiotics in Agriculture}

Two pamphlets, Statutory Instruments Nos. 1172 and 1174,1953 (London: H.M.S.O.; $2 d$. each), have recently been issued by the Ministry of Health in connexion with the use of aureomycin and penicillin; the regulations come into operation on September 1, 1953. Aureomycin, which is intended for parenteral injection, is added to substances coming under control of the Therapeutic Substances Act, 1925 (M.H. 220). At the same time, both penicillin and aureomycin, which by the Penicillin Act, 1947, cannot be used except under the direction of doctors, dentists and veterinary surgeons, are now allowed to be incorporated in pig and poultry food with certain safeguards (M.H. 246). Medical supplies of these substances will not be affected. A recent report by the Agricultural Research Council (A.R.C. Report No. 13) has shown that the addition of these substances to pig food increased the live weight gain from 10 to 14 per cent and improved the efficiency of food conversion by 6-7 per cent without affecting carcass quality.

\section{Nigerian Forest Administration : Annual Report for 1950-51}

The annual report for the year 1950-51 of the Nigerian Forest Administration (pp. 64. Lagos: Govt. Printer ; London: Crown Agents, 1952; $9 d$. net) provides food for reflexion and some uneasiness. After fifty years of a forest service in the country it is difficult to see that a sound basis of administration from the forestry point of view has been brought into force. The approach to forest conservation, instead of being made to the native chiefs by the administration service, was left to the forest officer, who possessed no administrative jurisdiction in the district except over the forest reserves. Consequently, in the south, where the heavy timber forests exist, the area reserved is said to be inadequate for a growing population. The big timber forests were expected to be a source of revenue to the country and the Forest Department was to obtain this revenue. It seems to have been overlooked that, in the past, the first call on the forests in a tropical and sub-tropical country is the provision of the requirements in small materials of the local agricultural population, and, secondly, or of equal importance, the maintenance of forests on the catchments of rivers and streams. For this purpose the government of the country requires to have at its elbow a senior forest expert who can advise on and guide the general forest policy and see that it is carried out throughout the several parts of the country. From the present report it appears that the Nigerian Forest Department is to be split up into three regional units each with its own chief oonservator, the whole being loosely knit under the influence, but not command, of an inspector-general of forests - a most ambiguous expression, so far as his responsibilities are concerned. Africanization of the Department is proceeding apace, and it is difficult to visualize the kind of forest administration and management which the British forest officers will apparently be handing over in due course to their African successors.

\section{Sheffield Organization for the Interchange of Tech- nical Publications}

THF twentieth annual meeting of the Organization for the Interchange of Technical Publications in Sheffield and District was held recently in the Central Library, Sheffield. The admission of the British Iron and Steel Research Association brought the total membership up to forty, including industrial establishments fifteen miles distant from the city. During the year 1,937 publications were interchanged, this being a record total. The meeting considered the difficulties caused by the lack of current indexes of Patent Office publications and urged the issue of weekly alphabetical name indexes in the official Journal, with quarterly and annual cumulations. A complete revision of the union list of periodicals and their files available in the libraries of nembers was 